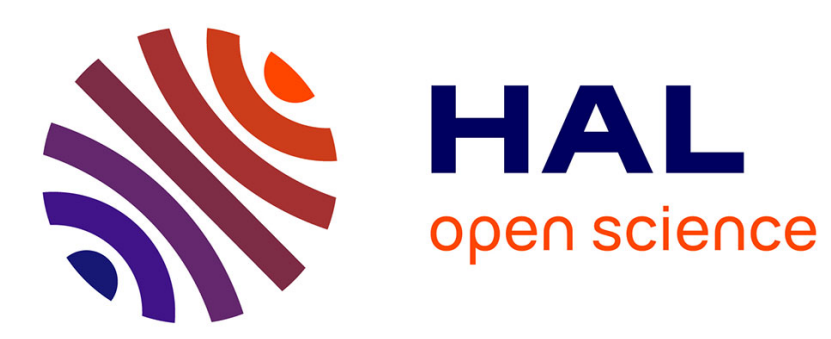

\title{
Women Work, Men are Professionals in the Old Assyrian Private Archives
}

Cécile Michel

\section{To cite this version:}

Cécile Michel. Women Work, Men are Professionals in the Old Assyrian Private Archives . Colloque international: "Travail et Société : la part du féminin / The Role of Women in Work and Society", Nov 2014, Nanterre, France. pp.193-208, 10.1515/9781614519089-012 . halshs-01674010

\section{HAL Id: halshs-01674010 \\ https://shs.hal.science/halshs-01674010}

Submitted on 6 Jan 2018

HAL is a multi-disciplinary open access archive for the deposit and dissemination of scientific research documents, whether they are published or not. The documents may come from teaching and research institutions in France or abroad, or from public or private research centers.
L'archive ouverte pluridisciplinaire HAL, est destinée au dépôt et à la diffusion de documents scientifiques de niveau recherche, publiés ou non, émanant des établissements d'enseignement et de recherche français ou étrangers, des laboratoires publics ou privés. 
The Role of Women in Work and Society in the Ancient Near East 


\section{Studies in Ancient Near Eastern Records}

General Editor:

Gonzalo Rubio

Editors:

Nicole Brisch, Petra Goedegebuure, Markus Hilgert, Amélie Kuhrt, Peter Machinist, Piotr Michalowski, Cécile Michel, Beate Pongratz-Leisten, D. T. Potts, Kim Ryholt

\section{Volume 13}




\section{The Role of Women in Work and Society in the Ancient Near East}

Edited by

Brigitte Lion and Cécile Michel 
ISBN 978-1-61451-913-3

e-ISBN (PDF) 978-1-61451-908-9

e-ISBN (EPUB) 978-1-61451-997-3

ISSN 2161-4415

\section{Library of Congress Cataloging-in-Publication Data}

A CIP catalog record for this book has been applied for at the Library of Congress.

\section{Bibliographic information published by the Deutsche Nationalbibliothek}

The Deutsche Nationalbibliothek lists this publication in the Deutsche Nationalbibliografie; detailed bibliographic data are available on the Internet at http://dnb.dnb.de.

(C) 2016 Walter de Gruyter Inc., Boston/Berlin Typesetting: Meta Systems Publishing \& Printservices GmbH, Wustermark Printing and binding: CPI books $\mathrm{GmbH}$, Leck

(2) Printed on acid-free paper

Printed in Germany

www.degruyter.com 


\section{Contents}

Foreword - $\mathbf{v}$

Acknowledgements - vii

Brigitte Lion and Cécile Michel

Women and Work in the Ancient Near East: An introduction -1

Catherine Breniquet

Weaving, Potting, Churning: Women at work during the Uruk period

Evidence from the cylinder seals $-\mathbf{8}$

Camille Lecompte

Representation of Women in Mesopotamian Lexical Lists - 29

Fumi Karahashi

Women and Land in the Presargonic Lagaš Corpus - 57

Maria Giovanna Biga

The Role of Women in Work and Society in the Ebla Kingdom

(Syria, $24^{\text {th }}$ century BC) -71

Massimo Maiocchi

Women and Production in Sargonic Adab - 90

Adelheid Otto

Professional Women and Women at Work in Mesopotamia and Syria ( $3^{\text {rd }}$ and early $2^{\text {nd }}$ millennia $B C$ ): The (rare) information from visual images - 112

Bertrand Lafont

Women at Work and Women in Economy and Society during the Neo-Sumerian Period — 149

Agnès Garcia-Ventura

The Sex-Based Division of Work versus Intersectionality: Some strategies for engendering the Ur III textile work force -174 
Cécile Michel

Women Work, Men are Professionals in the Old Assyrian Archives - 193

Jerrold S. Cooper

The Job of Sex: The social and economic role of prostitutes in ancient

Mesopotamia 209

Jana Matuszak

"She is not fit for womanhood": The Ideal Housewife According to Sumerian Literary Texts - 228

Ichiro Nakata

Economic Activities of nadītum-Women of Šamaš Reflected in the Field Sale Contracts (MHET II/1-6) 255

Katrien De Graef

Cherchez la femme!

The Economic Role of Women in Old Babylonian Sippar - $\mathbf{2 7 0}$

Nele Ziegler

Economic Activities of Women According to Mari Texts

(18 ${ }^{\text {th }}$ century BC) -296

Sophie Démare-Lafont

Women at Work in Mesopotamia: An attempt at a legal perspective - 310

Matteo Vigo

Sources for the Study of the Role of Women in the Hittite

Administration -328

Brigitte Lion

Work and Gender in Nuzi Society — 354

Josué J. Justel

Women in Economic Agreements: Emarite sale contracts

(Syria, $13^{\text {th }}$ century BC) -371

Masamichi Yamada

The kubuddā'u-Gift in the Emar Texts - 388 
Eiko Matsushima

Women in Elamite Royal Inscriptions: Some observations - 416

Virginie Muller

Women and their Activities in Divinatory Texts — 429

Saana Svärd

Studying Gender: A Case study of female administrators in Neo-Assyrian palaces -447

Francis Joannès

Historiography on Studies Dedicated to Women and Economy during the Neo-Babylonian Period 459

Louise Quillien

Invisible Workers: The role of women in textile production during the $1^{\text {st }}$ millennium $B C-473$

Yoko Watai

Economic Activities of Women in $1^{\text {st }}$ Millennium Babylonia -494

Laura Cousin

Beauty Experts: Female perfume-makers in the $1^{\text {st }}$ millennium $B C-512$

Julien Monerie

Women and Prebends in Seleucid Uruk -526

Violaine Sebillotte Cuchet

Women and the Economic History of the Ancient Greek World:

Still a challenge for gender studies -543

Index of professions and activities -565 
Brigitte Lion and Cécile Michel - 9781614519089 Downloaded from De Gruyter Online at 09/21/2016 02:07:27PM via De Gruyter / TCS 


\section{Cécile Michel}

\section{Women Work, Men are Professionals in the Old Assyrian Archives}

The Old Assyrian private archives are predominantly of a commercial nature; however, compared to other cuneiform corpuses, they include a large proportion of texts related to women and their activities. These texts show that wives and daughters of the Assyrian merchants, both at Aššur and Kaneš, enjoyed considerable independence both socially and economically. Various types of family records, such as marriage and divorce contracts, as well as testaments, bear witness to the status of Assyrian women, mainly in Kaneš. The letters Aššur women sent to their relatives in Kaneš reflect their preeminent role on the home front as well as their contribution to long distance trade. In addition, a few texts refer to the activities of the Anatolian women in Kaneš, especially those married to Assyrian merchants.

This essay focuses on the gender-specific division of work in Old Assyrian sources, and how female activities were perceived. After some definitions and a quick presentation of the sources and their authors, an inventory of male and female professions will be given and the rare female professions attested will be compared with women's activities in various spheres.

\section{Definitions and sources}

\subsection{Occupation, profession, work and job}

There are many English words referring to human activities, which need to be clarified before studying women's work in the Old Assyrian period from a gender perspective; among these are profession, job, occupation and work. A "profession" is understood as an activity performed by a person who went through a specific training or education. ${ }^{1}$ The words "job" and "occupation" include

1 For these definitions, see http://dictionary.cambridge.org/dictionary/essential-british-english/.

Acknowledgements: I address my warmest thanks to Benjamin Foster who kindly corrected the English of this article.

Cécile Michel, CNRS, Archéologies et Sciences de l'Antiquité, Nanterre; cecile.michel@mae.cnrs.fr 
profession; they correspond to an activity performed for compensation. "Work" has an even wider meaning: it corresponds to a task assigned either by oneself or by someone else and which has to be accomplished. Work can be interpreted quite broadly; it includes, for example, house work. A job or an occupation is thus work that is paid, independent of any training or qualification. It is also important to distinguish between occupation and status, which is an accepted or recognized social, legal or economic position. For example, the word hapirum refers, in the beginning of the $2^{\text {nd }}$ millennium $\mathrm{BC}$, to displaced persons; these persons could occasionally be ascribed to specific occupations (Durand 2005). In this paper, which explores the work performed by women and men in the Old Assyrian sources, the word profession will be used when referring to specific designations as "weaver”, “cook”, “midwife”, etc.

\subsection{The Old Assyrian Sources: what they say, what they don't say}

The 22,500 Old Assyrian tablets excavated in the lower town of Kültepe belonged mainly to three generations of Assyrian merchants who settled there during the first half of the $19^{\text {th }}$ century BC. The great majority of the dated texts - which represent $5 \%$ of the available sources - are concentrated in a sixty-year period (ca. 1895-1835), and it has been suggested that this is the case for the bulk of our documentation. ${ }^{2}$

According to modern categories, they can be classified into several text genres: letters, contracts and juridical texts, personal memoranda, lists, and a few non-commercial texts. ${ }^{3}$ The letters form the largest group, being the private correspondence exchanged among the Assyrian merchants in Kaneš and their families and colleagues in Aššur or in other Assyrian towns in Anatolia. ${ }^{4} \mathrm{Nu}$ merous commercial and family contracts excavated at Kaneš involve both the Assyrians and the Anatolians established in the lower town. Like other legal texts - verdicts, proceedings, private summons -, they deal with commercial and financial matters (Hertel 2013). The remaining group of tablets written for commercial purposes consists of anonymous private accounts, memoranda,

2 Barjamovic et al. 2012. Note however that some groups of letters are the oldest texts kept in archives, Michel 2008b.

3 For studies on the Old Assyrian archives, see for example Michel 1998; Larsen 2002; Veenhof 2003; Larsen 2008; Michel 2008a; Veenhof 2013. More generally, see the catalogue of Old Assyrian tablets and the bibliography in Michel 2003; Michel 2006a and Michel 2011a.

4 Michel 2001, with an overview of letters written to or by women, 417-511. 
lists of names, or distribution of goods to various people (Ulshöfer 1995). All these texts are predominantly connected with the long distance trade the Assyrians initiated between Aššur and Central Anatolia. However, because of the displacement of families between Aššur and Anatolia, they also document family matters and everyday life both in Aššur and in Kaneš.

Before analyzing the role of women in work and society through the Old Assyrian archives, one needs to understand who wrote the texts, what these texts tell and what they do not tell.

How many individuals were involved in writing so many tablets? School texts document a scribal education for some merchants who produced neatly written tablets with well-formed signs. It has been suggested that, because of the enormous number of letters found at Kaneš, a significant percentage of the Assyrian population was able to read and write (Michel 2008c). Indeed, the Old Assyrian syllabary is quite simple and limited, and could be learned without following specific courses and long training. The grammar and syntax of letters are sometimes substandard, and they use vernacular language. These letters seem to have been mostly written by the merchants themselves, who were traveling extensively and could not always have a scribe at hand. Many women sent letters from Aššur; their prose is often full of emotion (Larsen 2001). They were themselves involved in commercial and financial operations and owned personal archives. Several women were able to read, classify and write tablets; a legal document explicitly mentions a commercial tablet written down by a woman (Michel 2009a, 268-269).

The great majority of the texts were produced by men, documenting a male world and male occupations, mainly linked to trade. Women, participating less than men in international trade, are thus less visible. Also, the family trees reconstructed by Assyriologists regularly lack female members. Women are however still visible, especially those living alone in Aššur and sending letters to Anatolia. The archive unearthed in 1993, belonging to Ali-ahum and his son Aššur-taklāku, is a good case study; it shows that documented married women are those who entered the family by marriage. Unmarried young girls are rarely mentioned, usually only on the occasion of their marriage; they then leave the family to enter their husband's family (Michel 2015a). The activities of women attested in this archive are those more generally observed for Assyrian women in the Old Assyrian sources. Married women in Aššur managed their households and participated in textile production and export to Anatolia. Married women in Kaneš were in charge of the household - including the archives when their husbands were away. Unmarried adult women, usually consecrated to a deity, acted independently in financial matters and were involved in the disposition of their fathers' estates. 


\subsection{Old Assyrian society and Old Anatolian society}

The Aššur population was divided among Aššur, Kaneš and other trade settlements in Anatolia. Various studies have been published trying to estimate the Assyrian population in Aššur and Kaneš, as well as the total Kaneš population. Even if the Old Assyrian levels in Aššur have not been excavated, it seems to be accepted that, at the beginning of the $2^{\text {nd }}$ millennium $\mathrm{BC}$, the city did not exceed 55 hectares, and was composed of between 7,000 and 10,000 inhabitants (Larsen 2000, 79). Kaneš was much bigger, between 170 and 230 hectares, and its population amounted to 25,000 or 30,000 persons (Barjamovic 2014), including some 3,000 to 3,500 inhabitants living in the 9 hectares of the lower town commercial district. Among these, there was a majority of Assyrians, all of them involved in trade (Hertel 2014). Since the documentation was found in the houses of these merchants, our data give a picture restricted to the people in Aššur and in Kaneš mainly involved in long distance commerce. For Aššur, we find, in connection with international exchanges, the king and his sons, the eponyms and other high officials, priests and temples' staff, heads of wealthy families, etc. As a consequence, many attested occupations are directly linked to trade and caravan enterprises. The same observation can be made for the population of the Kaneš lower town since we have only the archives of the commercial district.

The data concerning Anatolian society are even more biased since it is documented only through its contacts with the Assyrian population. Indeed, very few Anatolians left archives. Written in a borrowed language and script, these archives are mainly made up of contracts, especially loan contracts, and a few family contracts (Michel 2011b). So our data concerning Anatolian occupations are to be found in the Assyrian archives. Besides the exercise of authority and trade activities, the Anatolians provided food to the Assyrians who were not involved in agriculture and herding.

All these observations concerning the authors and owners of archives must be taken into account when analyzing the role of women in work and society in a gender-oriented perspective.

\section{Male and female professions in the Old Assyrian Sources}

Professions attested in the Old Assyrian sources have already been inventoried (Michel 2015b); the results of this study are summarized below. Profes- 
sions are usually mentioned in distribution lists or other laconic contexts which do not give details about the activities of professionals; these are usually anonymous.

I will leave aside all the officials, both Assyrians and Anatolians. Their titles could sometimes be linked to a professional occupation. However it is interesting to note that all the Assyrian officials mentioned in the texts are men (Dercksen 2004), and no queen is attested at the side of the kings of Aššur. Assyrian authorities and officials in Anatolia - hamuštum, šiprum, țupšarrum, etc. - are also only men. As for the Anatolians, the fifty known Anatolian officials are all men (Veenhof 2008, 220-233; Michel 2014b, 120-122). However, we must take into account that the local dialect did not make any gender distinction and we cannot completely exclude that some male official titles could have exceptionally concealed some women. This is suggested by the fact that some towns were ruled by a royal couple or by a queen alone (Michel 2001, 163-167).

As already observed, Old Assyrian texts focus on trade, thus trade professionals and jobs linked to international trade are the most frequent: bankers, traders, transporters, freighters, donkey drivers, porters, agents; all these are male professions.

When we look at professions concerned with food production and preparation, there is a little more diversity. When a professional is mentioned, his ethnicity is not necessarily given, be it Assyrian or Anatolian. It was possible to identify a male Anatolian cook (nuhittimum), two male Assyrian confectioners (kakardinnum), a male Anatolian oil peddler (pāširum ša šamnim) and an oil trader (̌̌a šamnim), a male salt trader (̌̌a țābtim), male Anatolian gardeners (nukiribbum), and male Anatolian shepherds (ré'um). The only female occupation in food preparation is the flour grinder (té'ittum), but flour grinders are usually slaves. ${ }^{5}$ Inn-keeper was the only job exercised by both men and women: an Assyrian male inn-keeper (sābium) is known at Kaneš and an Amorite female inn-keeper (sābitum) is attested at Hattuš. ${ }^{6}$

The world of craft professionals looks again like a purely male one. Bricklayer (itinnum), metallurgist (nappāhum), carpenter (naggārum), bow maker (šasinnum), seal engraver (parkullum), potter (pahhārum), and leatherworker

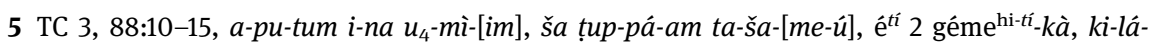
al-tí-ma, ù té-i-té-en 6 ki-la-a[l]-tí-m[a], a-na [ši-mì-im dí-ma], "Please, the very day you hear (this) tablet, offer for sale the houses, both of your slave girls and both of the grinding girls." Text edited by Larsen 2002, no. 40.

6 For a recent study on Old Babylonian inn-keepers, see Lion 2013. 
(aškāpum) are all jobs attested in the masculine, both in Aššur and Kaneš. Even professions linked to textile production are known only with the masculine gender: an Assyrian male weaver (ušpārum), as well as the cleaner specialized in the finishing and washing of textiles (ašlākum). There is also mention of a male barber (gallābum).

Few legal occupations are known; they are all held by men: judge (dayy $\bar{a}-$ num), attorney (rābișum), scribe (țupšarrum).

Female jobs are linked with social life, more precisely, as one might expect, with the care of children. Thus we find the following professions: midwife (šabsūtum), nurse (ēmiqtum) and wet-nurse (mušēniqtum), which is the only gender-based profession.

In the religious sphere, we find women as well, but these are not clearly associated with the temples, contrary to men. The temple was administered by the sangûm. A sangûm gave his name to a year as eponym (Elālī). Priests (kumrum) of Adad, Aššur, Ištar, Suen, Šamaš, and Šarra-mātēn are mainly referred to for their role in trade (Hirsch 1972, 55-59). It is interesting to note that women involved in the public life of Aššur were concentrated in the religious sphere; several occupations linked to religious practices were traditionally held by women, such as dream diviner (šẩiltum) and omen diviner (bāritum). These professionals were consulted by women as well (Michel 2009b). The consecration of a girl as gubabtum or qadištum conferred her upon a special social and religious status which certainly entailed specific responsibilities or tasks, but these were not necessarily compensated, so we usually see the gubabtum women living independently in Aššur and acting as businesswomen, initiating commercial and financial operations.

This inventory of occupations is very incomplete because of the nature of the sources. Many other professions are implied by the texts but are not explicitly mentioned. For example, distribution lists of breads suggest the existence of professional bakers (Michel in press b).

\section{Women's activities not referred to as professions}

In contrast to men, women seem to be rarely attested as professionals in Old Assyrian sources. However, they appear very active in various domains. To understand this paradox, we need to explore female activities. 


\subsection{Housewives: unrecognized and unpaid work}

From an Assyrian man's perspective, the basic duties of a wife were to give him children, to keep house, to serve her husband and to prepare his meals, as we read in the following letter sent by Puzur-Aššur to his fiancée Nūhšatum: ${ }^{7}$

\footnotetext{
"Your father wrote to me about you that I marry you, and I sent my servants and my letter about you to your father so that he lets you go. Please, the day you hear my tablet there, appeal to your father (so that he agrees), set out and come here with my servants. I am alone. There is no one to serve me and set my table."
}

Women, who did not accompany their husbands to Anatolia remained at Aššur in charge of their households. Their loneliness was well known, as witness the remark of Aššur-malik reproaching Aššur-idī for having forgotten him: ${ }^{8}$

"Why have you kept me confined inside the City (of Aššur) for 10 months, like a woman?”

These women were active in various capacities that reflect the daily life of women at home, as well as their roles as heads of families: education of children, care of the elderly, management of servants, supplying food to the household, maintenance of the house, weaving textiles for members of the household to wear, etc. Besides these typical housewife's tasks, they had to represent their husbands in various business transactions and to produce textiles for export to Anatolia (see section 3.2).

In Kaneš, wives had also to deal with their husbands' frequent absences. Beside the duties of a housewife, they had to keep track of everything in the home: furnishings and utensils, documents, and merchandise.

The manifold activities of women as housewives were never recognized as "work".

7 Michel in press a, no. 3 (BIN 6, 104): 3-18, a-bu-ki : a-šu-mi-ki [a-na], șé-ri-a a-na a-ha-[ziki], iš-pu-ra-am ù a-na-ku, șú-ha-ri-a ù na-áš-pè-er-tí, a-șé-er : $a$-bi-ki : $a$-šu-mì-ki, a-na šé-șú-iki, áš-ta-áp-ra-am a-pu-tum, i-na dutusi țup-pí, ta-áš-me-i-ni : a-ma-k[am], a-na a-bi-ki : pu-nu[i-ma], iš-tí șú-h[a]-ri-a, té-eb-e-ma a-tal-ki-im, we-da-ku : ma-ma-an : ša i-/na, re-šé-e-a : i-zazu-ma, pá-šu-ra-am : i-ša-kà-na-/ni, lá-šu.

8 CCT 4 45b:16-19, mì-šu-um : ki-ma, sí-ni-iš-tim : iš-tù iti-10-kam, i-qé-ra-áb : A-lim ${ }^{\mathrm{ki}}$, ta-áp-ta$a h-a-n i-i$. Both names are very common and we do not know if these two merchants belonged to the same family. 


\subsection{Textile production: Women acting as professionals but not recognized as such}

The inventory of professionals attested in Old Assyrian sources includes men specialized in weaving and finishing textiles, but no feminine profession linked to textile production in mentioned. We know very well, of course, that Aššur women spent much of their lifetime producing textiles for the international trade with Anatolia, and that they were paid in return for their production. They are, however, not referred to as weavers in the texts! ${ }^{9}$ Even if there is scarce documentation on the organization of the private textile production in Aššur, it is possible to estimate the income women could earn from it; this may be summarized as follows. ${ }^{10}$

In healthy households, a dozen women, including children, elderly women and slaves, spun and wove throughout the year both the clothes for the family and textiles to be sent to Anatolia. ${ }^{11}$ Letters give recommended dimensions for a kutānum-textile to be sent to Anatolia: $4 \times 4,5$ meters, which corresponds presumably to two sewn pieces. According to transport contracts, such a kutānum-textile weighed about 5 minas $(2.5 \mathrm{~kg})$.

Washing the wool and preparing 5 minas for spinning would have taken some 20 days of work for one person. ${ }^{12}$ Experiments carried out at the Centre for Textile Research in Copenhagen have shown that it is possible, using ancient tools, to spin some 50 meters of thread per hour. ${ }^{13}$ To weave a square meter of fabric, one needs about $2 \mathrm{~km}$ of thread, plus 2 to $5 \%$ for the setting of the loom. To obtain these $2 \mathrm{~km}$ of thread, a woman would have to spin for 5 days. ${ }^{14}$ The Assyrian textiles measuring $18 \mathrm{~m}^{2}$ required $36 \mathrm{~km}$ of thread for the weaving, and about 3 months of spinning for a single woman, while the

9 Michel 2006b; Michel 2013; Thomason 2013.

10 Michel 2013; Michel in press a, chapter 4: "Businesswomen"; sub-chapter: "Weaving as a lucrative profession."

11 We suppose that in the context of private production for the international trade, production ran throughout the year.

12 According to an Ur III text, a person would prepare about $125 \mathrm{~g}$ of wool a day, see Waetzoldt 2010, 207.

13 Andersson Strand 2012, 34. This research is in progress; it includes a study of Kültepe textiles imprints and textiles tools by E. Andersson Strand, C. Breniquet and C. Michel. It is carried out within the framework of the Groupe de Recherche International Ancient Textiles from the Orient to the Mediterranean (ATOM 2015-2018), http://www.mae.u-paris10.fr/gdriatom-presentation-eng/.

14 Nowadays, women maintaining a traditional production of textiles in the Near East weave for sixth to eight hours a day besides their domestic tasks, according to interviews with women in Bani Hamida (Jordan) and Çavdar (Turkey). 
setting of the two looms required 4 more days of work. According to hands-on experiments, one person can weave about $50 \mathrm{~cm}$ per day of work, depending, of course, on the width of the loom (Andersson Strand 2012, 35). So we obtain the following figures:

Tab. 1: Number of day's work for an Assyrian to produce a kutānum-textile.

\begin{tabular}{ll}
\hline Tasks to produce a woolen textile weighing & Number of day's work for one woman \\
$\mathbf{5}$ minas and measuring $\mathbf{4} \times \mathbf{4 , 5}$ meters & \\
\hline Cleaning and combing & 20 \\
Spinning & 94 \\
Setting of the loom(s) & 8 \\
Weaving & 20 \\
\hline Total of working days/woman & 142 \\
& {$[43 / 4$ months] } \\
\hline
\end{tabular}

Thus a woman could finish some $21 / 2$ such textiles a year, and a wealthy household would produce about 25 textiles a year. Of these, 5 large pieces would be necessary to clothe the members of the household. Thus, 20 textiles could be sent to be sold in Anatolia. ${ }^{15}$

The sale of their textiles in Anatolia assured an income to Aššur women. They were paid by the piece, allowing computation of the income per garment. The current kutānum-textile produced by Aššur women was sold 15 shekels at Kaneš. After taxes were deducted, women could hope to get back 10 to 12 shekels per piece. The price of the wool in Aššur was about 15 minas per shekel, and the loss during cleaning was about $30 \%$ of the original wool; thus with 1 shekel of silver it might have been possible to acquire about 10 minas of cleaned wool, which could be used to weave 2 textiles. Taking into account that a third of the sale price of a textile was invested in the purchase of wool to produce new textiles, we may estimate that a household producing yearly some 20 textiles sent for trade to Anatolia would receive between $31 / 2$ and 4 minas of silver per year as gross income, corresponding to the price of a small house in Aššur (Veenhof 2011). Regular shipping of textiles guaranteed Aššur women a substantial annual income.

15 Such an estimation was confirmed by Lamassīs letters showing that, within a year, she was able to send 25 textiles to her husband including those for his own garde-robe (see Michel in press a, chapter 4: "Businesswomen"), Michel 2013; Michel 2014a, 95-96. 


\subsection{Women as actors in trade and finance}

No profession connected with trade and finance concerns women, although they were quite active in both.

Tab. 2: Old Assyrian loan contracts involving men and women.

\begin{tabular}{llllll}
\hline & Only men & $\begin{array}{l}\text { Couples or } \\
\text { families }\end{array}$ & Women & $\begin{array}{l}\text { Women as } \\
\text { creditors }\end{array}$ & $\begin{array}{l}\text { Women as } \\
\text { debtors }\end{array}$ \\
\hline $\begin{array}{l}\text { Interest free loans } \\
(14.5 \% \text { of the loans })\end{array}$ & $69.5 \%$ & $21.5 \%$ & $9 \%$ & $5.5 \%$ & $3.5 \%$ \\
\hline $\begin{array}{l}\text { Loans with interest } \\
(25 \% \text { of the loans) }\end{array}$ & $92 \%$ & $5 \%$ & $3 \%$ & $3 \%$ & $0 \%$ \\
\hline $\begin{array}{l}\text { Loans with default interest } \\
(60.5 \% \text { of the loans })\end{array}$ & $86.5 \%$ & $6.5 \%$ & $7 \%$ & $5 \%$ & $2 \%$ \\
\hline average & $85 \%$ & $8.5 \%$ & $6.5 \%$ & $4.5 \%$ & $2 \%$ \\
\hline
\end{tabular}

There are about 400 published loan tablets excavated at Kaneš; ${ }^{16} 6.5 \%$ of these loan contracts involve at least one woman; in two-thirds of these she is a creditor and in one-third a debtor.

Women could lend silver either to men or women, Assyrians or Anatolians, but their loans tended to be smaller than those of men. ${ }^{17}$ They appear both in interest-free short term loans and in loans with default interest. They could also act as creditor in loans with interest, but were never debtors in such loans - being usually commercial and linked to the international trade - because they did not act as travelling agents. But this does not mean that they did not take part in the trade. A specific type of loan, the tadmiqtum-loan, was more typical for women. To send their textiles to Anatolia, they entrusted their textiles on favorable terms as a tadmiqtum or "good-faith consignment loan" to members of their families or agents travelling to Anatolia.

16 For OA loan contracts, http://www.d-o-c.fr/.

17 Michel 2014a, 97-98; Michel in press a, chapter 4 "Businesswomen," section "Women lend, buy and invest." Ahatum lent silver to Assyrian men at least four times. The four loans are dated within 9 years (TC 3, 228; BIN 4, 153; KTS 1, 45b; RA 59, 36). Šàt-Ana lent a total of 1 mina and 27 shekels of silver to different men according to three contracts (TC 3, 235; CCT 5, 20c; TC 3, 220). 
Beside their textile production, some women were clearly involved in longdistance trade, buying merchandise in Aššur to be sent for sale in Kaneš. ${ }^{18}$ They could invest in a caravan enterprise. ${ }^{19}$ There are also some rare mentions of women owing shares in joint-stock companies. Such a partnership involved several persons investing silver, which was made available to an agent on long term to gain profit from overland trade. Ahaha, the consecrated daughter of Pūšu-kēn, writes several letters to her brothers concerning her share in at least two such joint-stock companies (Michel 2001, nos. 225-226). The wife of Salliya bought a share in a joint-stock company administered by Iddin-Ištar. ${ }^{20}$ Contracts of this type regulated the relationships between the investors of Aššur and the agents in Anatolia; this was the main financing mode for the Assyrian trade in Anatolia. ${ }^{21}$

We also see women travelling on business (Michel 2008d), for example, the widow Ennam-Ištar who wrote to her son as follows:22 "In your presence, in Burušhattum, I gave 10 shekels of silver to Aššur-țāb. (Then) in Kaneš, I gave him a single kutānum-textile."

Single women, either consecrated or widows, as well as married women, were involved in financial operations similar to those operated by men. Some appear to have been excellent accountants. But they are less attested in such a role, and when they invest capital in gold or silver, the amount is usually smaller than the capitals invested by men. In any case, they are not considered professionals in these activities.

\subsection{Agricultural tasks of Anatolian women}

When the Assyrian merchants settled in Kaneš, they arrived alone, and some took Anatolian women as second wives there. As they were traveling within Anatolia or to Aššur, they sent letters to their Anatolian wives referring to their activities. Contrary to the main preoccupations of the women of Aššur, mostly eager to learn what was happening with their textile production, the Anatolian

18 A small contract lists consigned merchandise among which silver, textiles, wool, copper and donkeys belonging to the woman Bazaya; Michel in press a, no. 196, previously published by Bayram and Çeçen 1996, no. 5 (Kt 76/k 2).

19 Kulšan lend silver to merchants going on for one or two round trip caravan: Michel in press a, no. 188, previously published by Uzunalimoðlu 1992, 53-54 (Kt n/k 860).

20 CTMMA 185.

21 Larsen 1977; Hecker 1999; Veenhof 1999.

22 AKT 6a, 223:3-8, ma-ah-ri-kà-ma, i-na Bu-ru-uš-ha-tim, 10 gín kù-babbar : $a$-na A-šùr-du ${ }_{10}$, a-dí-in i-na Kà-ne-eš ${ }_{15}$, iš-té-en 6 túg ku-ta-nam, a-dí-šu-um. 
women of Kaneš never speak about textile production. However, some texts, as well as archaeological artifacts excavated in Kültepe's lower town, such as spindle whorls and loom weights, announce such a production. As with the women in Aššur, the occupations of the Anatolian wives are domestic or commercial. But unlike Assyrian women, Anatolian women also performed agricultural work (Michel 2008e). Šišahšušar, Aššur-nādā's wife, bought oxen and had to find enough fodder for them; then she got them ready for ploughing. She also bought straw, wood, reeds and many tools for the house and for field work. ${ }^{23}$ Kunnanīya received instructions from her husband Aššur-mūtappil about the pigs she was breeding. ${ }^{24}$ As was still the case in France half a century ago, the agricultural activities of women were not recognized as professional in nature.

The inventory of professions occurring in Old Assyrian texts shows predominantly men at work. They were brought up as professionals, often learning their future job from their fathers. They practiced their profession outside the home, in a workshop, in institutional buildings, or by travelling.

Women are rarely mentioned as professionals, except in specific spheres. In the context of food preparation and sale, we find flour grinders and tavernkeepers. Diviners and dream diviners belonged to the religious sphere. Midwives, nurses and wet-nurses undertook the care of children. However, Assyrian women appear as very active, both as housewives and heads of households, and in their contribution to the international trade. When producing textiles for Anatolia, they acted as true professionals. Indeed, their skills were recognized abroad, and they were paid for their work as weavers. With the money they earned, which built up their personal assets, independent of their husband's, they invested in trade and initiated financial operations. However, they are never mentioned as "professional" weavers. Perhaps we can see here the idea that work done at home is not considered a job, an idea later developed by Xenophon (Oeconomicus, chap. VII) in Greece.

23 See TC 2, 47; translated by Michel 2001, no. 358 and Larsen 2002, no. 52, and VS 26, 20; edited by Larsen 2002, no. 58.

24 BIN 6, 84 mentioned by Michel 2006c, 171, n. 7. 


\section{Abbreviation}

AKT 6a Larsen, Mogens T. 2010. The Archive of the Šalim-Aššur Family. Volume 1: The First Two Generations. Kültepe Tabletleri VI - a. Ankara: Türk Tarih Kurumu Basımevi.

\section{Bibliography}

Andersson Strand, Eva. 2012. The Textile chaîne opératoire: Using a Multidisciplinary Approach to Textile Archaeology with a Focus on the Ancient Near East. Pp. 21-40 in Prehistory of Textiles in the Ancient Near East, eds. Catherine Breniquet, Margareta Tengberg \& Eva Andersson Strand with the collaboration of Marie-Louise Nosch. Paléorient 38: 21-40.

Atıcı, Levent, Fikri Kulakoğlu, Gojko Barjamovic, and Andrew Fairbairn (eds.). 2014. Current Research at Kultepe/Kanesh. An Interdisciplinary and Integrative Approach to Trade Networks, Internationalism, and Identity. JCS Supplemental Series 4. Atlanta: Lockwood Press.

Barjamovic, Gojko. 2014. The Size of Kanesh and the Demography of Early Middle Bronze Age Anatolia. Pp. 55-68 in Atıcı et al. 2014.

Barjamovic, Gojko, Thomas K. Hertel, and Mogens T. Larsen. 2012. Ups and Downs at Kanesh. Chronology, History and Society in the Old Assyrian Period. Old Assyrian Archives Studies 5. PIHANS 120. Leiden: Nederlands Historisch-Archaeologisch Instituut Leiden.

Bayram, Sabahattin and Salih Çeçen. 1996. The Institution of Slavery in Ancient Anatolia in the Light of New Documents. Belleten 60: 606-645.

Dercksen, Jan Gerrit. 2004. Old Assyrian Institutions. PIHANS 98. Leiden: Nederlands Historisch-Archaeologisch Instituut Leiden.

Durand, Jean-Marie. 2005. Assyriologie. Le problème des haBirum et l'étymologie du terme "hébreu". Cours et travaux du Collège de France, 563-584

http://www.college-de-france.fr/media/jean-marie-durand/UPL19772_ durandres0405.pdf.

Fares, Saba, Françoise Briquel-Chatonnet, Brigitte Lion, and Cécile Michel (eds). 2009. Femmes, cultures et sociétés dans les civilisations méditerranéennes et prochesorientales de l'Antiquité. Topoi Suppl. 10.

Hecker, Karl. 1999. In nova ... ArOr 67: 557-565.

Hertel, Thomas K. 2013. Old Assyrian Legal Practices. Law and Dispute in the Ancient Near East. Old Assyrian Archives Studies 6. PIHANS 123. Leiden: Nederlands HistorischArchaeologisch Instituut Leiden.

Hertel, Thomas K. 2014. The Lower Town of Kültepe: Urban Layout and Population. Pp. 25-54 in Atıci et al. 2014.

Hirsch, Hans. 1972. Untersuchungen zur altassyrischen Religion. AfO Beiheft 13/14. Graz: Im Selbstverlage des Herausgebers.

Larsen, Mogens T. 1977. Partnerships in the Old Assyrian Trade. Iraq 39: 119-149.

Larsen, Mogens T. 2000. The Old Assyrian City-State. Pp. 77-87 in A Comparative Study of Thirty City-Sate Cultures, ed. Mogens H. Hansen. Copenhagen: Kongelige Danske Videnskabernes Selskab. 
Larsen, Mogens T. 2001. Affect and Emotion. Pp. 275-286 in Veenhof Anniversary Volume. Studies Presented to Klaas R. Veenhof on the Occasion of his Sixty-Fifth Birthday, ed. Wilfred H. van Soldt. PIHANS 89. Leiden: Nederlands Historisch-Archaeologisch Instituut Leiden.

Larsen, Mogens T. 2002. The Aššur-nādā Archive. Old Assyrian Archives 1. PIHANS 96. Leiden: Nederlands Historisch-Archaeologisch Instituut Leiden.

Larsen, Mogens T. 2008. Archives and Filing Systems at Kültepe. Pp. 77-88 in Old Assyrian Studies in Memory of Paul Garelli, ed. Cécile Michel. Old Assyrian Archives Studies 4. PIHANS 112. Leiden: Nederlands Historisch-Archaeologisch Instituut Leiden.

Lion, Brigitte. 2013. Les cabarets à l'époque paléo-babylonienne. Pp. 393-400 in L'alimentation dans l'Orient ancien: Cuisines et dépendances, ed. Cécile Michel. Cahiers des thèmes transversaux d'ArScAn. Vol. XI, 2011-2012. Nanterre: Archéologies et Sciences de l'Antiquité. http://www.mae.u-paris10.fr/arscan/IMG/pdf/Cahier_des_ ThemesXI_Th_9_Lion.pdf.

Michel, Cécile. 1998. Quelques réflexions sur les archives récentes de Kültepe. Pp. 419-433 in 3. Uluslararası Hititoloji Kongresi Bildirileri, eds. Sedat Alp and Aygül Süel. Ankara: Uyum Ajans. http://halshs.archives-ouvertes.fr/halshs-00708857.

Michel, Cécile. 2001. Correspondance des marchands de Kaniš au début du Ile millénaire av. J.-C. Littératures du Proche-Orient ancien 19. Paris: Editions du Cerf.

Michel, Cécile. 2003. Old Assyrian Bibliography of Cuneiform Texts, Bullae, Seals and the Results of the Excavations at Aššur, Kültepe / Kaniš, Acemhöyük, Alişar and Boğazköy. Old Assyrian Archives Studies 1. PIHANS 97. Leiden: Nederlands HistorischArchaeologisch Instituut Leiden.

Michel, Cécile. 2006a. Old Assyrian Bibliography 1 (February 2003-July 2006). AfO 51: 436449.

Michel, Cécile. 2006b. Femmes et production textile à Aššur au début du II millénaire avant J.-C. Techniques \& culture 46: 281-297. http://halshs.archives-ouvertes.fr/halshs-00821277.

Michel, Cécile. 2006c. Les suidés dans la documentation de Kaniš au début du IIe millénaire avant J.-C. Pp. 169-180 in De la domestication au tabou: le cas des suidés au ProcheOrient ancien, eds. Brigitte Lion and Cécile Michel. Travaux de la Maison René-Ginouvès 1. Paris: De Boccard. http://halshs.archives-ouvertes.fr/halshs-00518271.

Michel, Cécile. 2008a. The Alāhum and Aššur-taklāku archives found in 1993 at Kültepe Kaniš. AoF 35: 53-67 [abstract p. 359]. http://halshs.archives-ouvertes.fr/halshs-01186428.

Michel, Cécile. 2008b. La correspondance des marchands assyriens du xIX s. av. J.-C.: de l'archivage des lettres commerciales et privies. Pp. 117-140 in La lettre d'archive. Communication administrative et personnelle dans l'Antiquité proche-orientale et égyptienne, ed. Laure Pantalacci. Topoi Suppl. 9. Le Caire: IFAO. http://halshs.archives-ouvertes.fr/halshs-00644198/fr/.

Michel, Cécile. 2008c. Écrire et compter chez les marchands assyriens du début du II millénaire av. J.-C. Pp. 345-364 in Muhibbe Darga Armağanı, eds. Taner Tarhan, Aksel Tibet, and Erkan Konyar. Istanbul: Sadberk Hanım Müzesi. http://halshs.archives-ouvertes.fr/halshs-00443900/fr/.

Michel, Cécile. 2008d. Femmes au foyer et femmes en voyage: le cas des épouses des marchands assyriens au début du lle millénaire av. J.-C. Clio, Histoire, femmes et sociétés 28: 17-38. http://clio.revues.org/index7603.html. 
Michel, Cécile. 2008e. Les Assyriens et leurs femmes anatoliennes. Pp. 209-229 in Anatolia and the Jazira during the Old Assyrian Period, ed. Jan Gerrit Dercksen. Old Assyrian Archives Studies 3. PIHANS 111. Leiden: Nederlands Historisch-Archaeologisch Instituut Leiden. http://halshs.archives-ouvertes.fr/halshs-00667570.

Michel, Cécile. 2009a. Les femmes et l'écrit dans les archives paléo-assyriennes (XIXe s. av. J.-C.). Pp. 253-272 in Fares et al. 2009. http://halshs.archives-ouvertes.fr/halshs-00644211/fr/.

Michel, Cécile. 2009b. Les filles de marchands consacrées. Pp. 145-163 in Fares et al. 2009. http://halshs.archives-ouvertes.fr/halshs-00644209/fr/.

Michel, Cécile. 2011a. Old Assyrian Bibliography 1 (July 2006-April 2009). AfO 52: 396-417.

Michel, Cécile. 2011b. The Private Archives from Kaniš Belonging to Anatolians. Pp. 94-115 in Archival, Scribal, and Administrative Spaces among the Hittites, ed. Maria E. Balza. AoF 38. http://halshs.archives-ouvertes.fr/halshs-01186438.

Michel, Cécile. 2013. Assyrian Women's Contribution to International Trade with Anatolia. Second International Workshop of the French-Japanese ANR programme Chorus REFEMA (Rôle économique des femmes en Mésopotamie ancienne), Tokyo, June 2013. Online publication October 2013. http://refema.hypotheses.org/850.

Michel, Cécile. 2014a. The Economic Role of Women in the Old Assyrian Sources. Pp. 93-101 in Le role économique des femmes en Mésopotamie ancienne (REFEMA) / Women's Role in the Economy of the Ancient Near East, eds. Francis Joannès and Fumi Karahashi. Japan Society for the Promotion of Science: International Collaborations. Bilateral Joint Research Project with France (ANR). Report: December 31, 2011-December 30, 2014. Tokyo.

Michel, Cécile. 2014b. Central Anatolia in the Nineteenth and Eighteenth Centuries BC. Pp. 111-136 in Constituent, Confederate, and Conquered Space. The Emergence of the Mittani State, eds. Eva Cancik-Kirschbaum, Nicole Brisch, and Jesper Eidem. TOPOI. Berlin Studies of the Ancient World 17. Berlin: De Gruyter. http://www.degruyter.com/viewbooktoc/product/129816.

Michel, Cécile. 2015a. Women in the Family of Ali-ahum son of Iddin-Suen (1993 Kültepe archive). Pp. 85-93 in Proceedings of the $1^{\text {st }}$ Kültepe International Meeting, Kültepe, 1923 September, 2013. Studies Dedicated to Kutlu Emre, eds. Fikri Kulakoğlu and Cécile Michel. Kültepe International Meetings 1. Subartu XXXV. Turnhout: Brepols.

Michel, Cécile. 2015b. Were there only merchants at Aššur and Kaneš? Overview of professions attested in the Old Assyrian Sources. Pp. 171-184 in Cahit Günbattı'ya Armağan. Studies in Honour of Cahit Günbattı, eds. İrfan Albayrak, Hakan Erol and Murat Çayır. Ankara: Ankara Üniversitesi Basımevi.

Michel, Cécile. In press a. Women from Aššur and Kaniš according to the private archives of the Assyrian merchants at beginning of the $I^{\text {nd }}$ millennium B.C. Writings from the Ancient World. SBL. Baltimore.

Michel, Cécile. In press b. Le pain à Aššur et à Kaneš, Festschrift NN. AOAT, Stuttgart: Kevelaer and Neukirchen-Vluyn.

Thomason, Allison K. 2013. Her Share of the Profits: Women, Agency, and Textile Production at Kültepe/Kanesh in the Early Second Millennium BC. Pp. 93-112 in Textile Production and Consumption in the Ancient Near East. Archaeology, Epigraphy, Iconography, eds. Marie-Louise Nosch, Henriette Koefoed, and Eva Andersson Strand. Ancient Textiles Series 12. Oxford: Oxbow Books.

Ulshöfer, Andrea. 1995. Die altassyrischen Privaturkunden. FAOS Beiheft 4. Stuttgart: Franz Steiner Verlag. 
Uzunalimoğlu, Ayşe. 1992. 1950 Yılında Kültepe Kazısında Bulunan 5 Adet Mahkeme Kararı. Anadolu Medeniyetleri Müzesi Yıllığı 1990: 44-53.

Veenhof, Klaas R.1999. Silver and Credit in Old Assyrian Trade. Pp. 55-83 in Trade and Finance in Ancient Mesopotamia, ed. Jan Gerrit Dercksen. PIHANS 87. Leiden: Nederlands Historisch-Archaeologisch Instituut Leiden.

Veenhof, Klaas R. 2003. Archives of Old Assyrian Traders. Pp. 78-123 in Archives and Archival Tradition. Concepts of Record-Keeping in the Ancient World, ed. Maria Brosius. Oxford: Oxford University Press.

Veenhof, Klaas R. 2008. The Old Assyrian Period. Pp. 13-268 in Mesopotamia. The Old Assyrian Period, ed. Markus Wäfler. OBO 160/5. Fribourg: Academic Press Fribourg and Göttingen: Vandenhoeck \& Ruprecht.

Veenhof, Klaas R. 2011. Houses in the ancient city of Assur. Pp. 211-231 in Correlates of Complexity. Essays in Archaeology and Assyriology Dedicated to Diederik J. W. Meijer in Honour of his $65^{\text {th }}$ Birthday, eds. Bleda S. Düring, Arne Wossink, and Peter M. M. G. Akkermans. PIHANS 116. Leiden: Nederlands Historisch-Archaeologisch Instituut Leiden. Veenhof, Klaas R. 2013. The Archives of Old Assyrian Traders: their Nature, Functions and Use. Pp. 27-71 in Archives and archival documents in ancient societies: Trieste 30 September-1 October 2011, ed. Michele Faraguna. Legal documents in ancient societies IV. Trieste: Edizioni Università di Trieste.

Waetzoldt, Hartmut. 2010. The Colours and Variety of Fabrics from Mesopotamia during the Ur III Period (2050 BC). Pp. 201-209 in Textile Terminologies in the Ancient Near East and Mediterranean from the Third to the First Millennia $B C$, eds. Cécile Michel and Marie-Louise Nosch. Ancient Textiles 8. Oxford: Oxbow Books. 